\title{
INFLUENCE OF COIRPITH BASED CYANOBACTERIAL BASAL AND FOLIAR BIOFERTILIZER ON HIBISCUS ESCULENTUS
}

\author{
Abraham Christopher $\mathrm{P}^{1}$, Shantha Prema Raj ${ }^{2}$, Nandagopal $\mathrm{S}^{3}$ \\ ${ }^{182}$ Department of Microbiology, Dr. M.G.R. University, Chennai-600 095, Tamil Nadu, India. \\ ${ }^{3}$ Senior Lecturer, Department of Biotechnology, Sathyabama University, Chennai-600 119, Tamil Nadu, India. \\ E-mail : 'shanthamicrobio@gmail.com.
}

\section{ABSTRACT}

Growth promoting ability of coirpith based cyanobacterial $(C B+C P)$ basal and foliar biofertilizer application on Hibiscus esculentus was evaluated. Scrutiny of varying concentration of foliar spray revealed that $30 \%$ of foliar along with basal induced maximum growth and yield. The present investigation results were well supported by comparison of morphological and biochemical parameters in all the plants. The results indicated the presence of plant growth promoting substances in coir pith basal and foliar biofertilizer.

KEYWORDS: Oscillatoria annae; Coirpith; biofertilizer; foliar spray and Hibiscus esculentus.

\section{INTRODUCTION}

Biofertilizers are ecofriendly and are also called as microbial inoculants. The name implies biological origin and serves the function of supplying the nutrients for effective plant growth. The bioorganic fertilizer can increase the output; improve the quality of the crops responsible for agricultural environment.

Cyanobacteria are oxygenic photosynthetic free living and nitrogen fixing microorganisms in marine, freshwater and soil. The blue green color of cells is due to the combination of green chlorophyll pigment and a unique blue pigment (Phycocyanin). It is being used as a biofertilizer for plants food for cattles and man and medicinal products such as vitamins and drug compounds for human [1].

Coconut (Cocos nucifera L.) is cultivated in tropical countries. The fibrous mesocarp of coir is used to make ropes. The waste of coir yarn industry gets accumulated in large quantities and making their disposal difficult, though it is used as soil conditioner. Foliar spray could be used in many different growing medium for excellent production in organic farming, industries and home application such as gardening.

H. esculentus common name of lady's finger, okra. It is an annual herbaceous shrub. It has showy hibiscus flower. The edible part is the seed pod; it is actually a capsule. Okra is grown as a perennial and is a fast growing plant. The mucilage binds cholesterol and bile acid carrying toxins dumped into it by the liver. It helps to lubricate the large intestine due to its laxative qualities. The fiber in okra helps to stabilize blood sugar (It helps the rate at which sugar is absorbed from the intestinal tract).

\section{MATERIALS AND METHODS}

\section{A. Organism and culture conditions}

Pure culture of fresh water cyanobacteria, Oscillatoria annae was obtained from the germplasm of National Facility for Marine Cyanobacteria, Bharathidasan University, Tiruchirappalli, Tamil Nadu, India. The culture was maintained in BG11 medium [2] at 1500 lux at $25 \pm 2 \mathrm{C}$ in 14/10 light and dark cycle.

\section{B. Lignocellulosic material}

Coir pith was collected from coir pith industry, Tiruchirappalli, Tamilnadu, India.

\section{Experimental condition}

Log phase culture of cyanobacteria was taken and mixed with (1:10 ratio) coir waste and incubated for degradation process. The coirpith based cyanobacterial biofertilizer was filtered and dried for storage this coirpith used as basal biofertilizer and filtered supernatant was applied as foliar spray. Basal and foliar spray in various concentrations (10\%, 20\%, 30\%, 40\% \& 50\%) applied on plants which were treated as test and without any treatment plant acted as control. Finally, the morphological parameters like length of the root, shoot, and number of leaves, flowers, fruits and dry weight of Hibiscus esculentus were analyzed. Biochemical parameters were also analyzed such as chlorophyll [3] carotenoid [4] protein [5] total phenolics (6) and free amino acids [7].

\section{RESULTS AND DISCUSSION}

The increase in morphological, biochemical and yield of $H$. esculentus were observed with consecutive application of coirpith based cyanobacterial basal and foliar application.

Only in 30\% foliar spray observations showed marked increased in shoot length, leaves and number of flowers, fruits, dry weight of the root, shoot and leaves when compared to control and other treatments (Table -1). 
Table 1. Effect of coirpith based cyanobacterial biofertilizer on biochemical parameters and yield of Hibiscus esculentus

\begin{tabular}{|c|c|c|c|c|c|c|c|}
\hline $\begin{array}{c}\text { Root length } \\
(\mathbf{c m})\end{array}$ & $\begin{array}{c}\text { Shoot length } \\
\mathbf{( c m )}\end{array}$ & $\begin{array}{c}\text { Number of } \\
\text { leaves/plant }\end{array}$ & $\begin{array}{c}\text { Dry weight } \\
\text { of root } \mathbf{g m})\end{array}$ & $\begin{array}{c}\text { Dry weight of } \\
\text { shoot } \mathbf{( g m})\end{array}$ & $\begin{array}{c}\text { Dry weight of } \\
\text { leaves }(\mathrm{gm})\end{array}$ & $\begin{array}{c}\text { Number } \\
\text { of flowers/plant }\end{array}$ & $\begin{array}{c}\text { Number } \\
\text { of fruits/plant }\end{array}$ \\
\hline $9.0 \pm 0.12$ & $14.0 \pm 0.026$ & $3 \pm 0.024$ & $0.12 \pm 0.036$ & $0.26 \pm 0.043$ & $0.04 \pm 0.006$ & 1 & 1 \\
$15.0 \pm 0.013$ & $18.5 \pm 0.003$ & $12 \pm 0.001$ & $0.37 \pm 0.027$ & $0.74 \pm 0.018$ & $0.86 \pm 0.01$ & 3 & 3 \\
$24.0 \pm 0.033$ & $26.0 \pm 0.031$ & $13 \pm 0.021$ & $0.52 \pm 0.016$ & $1.06 \pm 0.026$ & $1.09 \pm 0.022$ & 4 & 4 \\
$28.0 \pm 0.042$ & $33.5 \pm 0.041$ & $15 \pm 0.031$ & $1.74 \pm 0.011$ & $3.72 \pm 0.015$ & $3.01 \pm 0.01$ & 7 & 7 \\
$16.0 \pm 0.036$ & $32.0 \pm 0.007$ & $14 \pm 0.040$ & $0.68 \pm 0.04$ & $2.26 \pm 0.028$ & $1.85 \pm 0.006$ & 5 & 5 \\
& & & & & & & 4 \\
$13.0 \pm 0.041$ & $20.0 \pm 0.023$ & $14 \pm 0.071$ & $0.38 \pm 0.018$ & $1.13 \pm 0.007$ & $1.40 \pm 0.012$ & 4 & 4 \\
\hline
\end{tabular}

Values are the mean of three replicates \pm SD.

Table 2. Comparison of biochemical parameters of coirpith based cyanobacterial biofertilizer treated and untreated Hibiscus esculentus

\begin{tabular}{|c|c|c|c|c|c|c|c|c|}
\hline $\begin{array}{l}\text { S. } \\
\text { No }\end{array}$ & Sample & $\begin{array}{c}\text { Total } \\
\text { chlorophyll } \\
\text { (mg/g) }\end{array}$ & $\begin{array}{l}\text { Chlorophyl } \\
(\mathrm{mg} / \mathrm{g})\end{array}$ & $\begin{array}{l}\text { Chlorophyl } \\
(\mathrm{mg} / \mathrm{g})\end{array}$ & Phenol ( $\mu \mathrm{g} / \mathrm{g})$ & Protein $(\mathrm{mg} / \mathrm{g})$ & $\begin{array}{c}\text { Carotenoid } \\
(\mathrm{mg} / \mathrm{g})\end{array}$ & $\begin{array}{c}\text { Amino acid } \\
(\mathrm{mg} / \mathrm{g})\end{array}$ \\
\hline 1. & Control & $0.23 \pm 0.017$ & $0.13 \pm 0.034$ & $0.02 \pm 0.001$ & $75.0 \pm 0.008$ & $160.0 \pm 0.01$ & $75.1 \pm 0.14$ & $18.0 \pm 0.132$ \\
\hline 2. & $10 \%$ basal + Foliar spray & $0.28 \pm 0.13$ & $0.17 \pm 0.02$ & $0.07 \pm 0.015$ & $115.0 \pm 0.08$ & $180.0 \pm 0.047$ & $128.8 \pm 0.016$ & $29.0 \pm 0.002$ \\
\hline 3. & $20 \%$ basal + foliar spray & $0.29 \pm 0.002$ & $0.18 \pm 0.011$ & $0.10 \pm 0.033$ & $150.0 \pm 0.01$ & $360.0 \pm 0.06$ & $156.4 \pm 0.012$ & $38.0 \pm 0.002$ \\
\hline 4. & $30 \%$ basal + foliar spray & $0.49 \pm 0.017$ & $0.34 \pm 0.003$ & $1.15 \pm 0.009$ & $347.5 \pm 0.015$ & $560.0 \pm 0.014$ & $203.4 \pm 0.015$ & $79.0 \pm 0.016$ \\
\hline 5. & $40 \%$ basal + foliar spray & $0.47 \pm 0.001$ & $0.29 \pm 0.013$ & $0.18 \pm 0.004$ & $77.5 \pm 0.007$ & $540.0 \pm 0.001$ & $149.1 \pm 0.005$ & $22.0 \pm 0.004$ \\
\hline 6. & $50 \%$ basal + foliar spray & $0.22 \pm 0.01$ & $0.13 \pm 0.023$ & $0.10 \pm 0.024$ & $65.0 \pm 0.004$ & $520.0 \pm 0.021$ & $145.0 \pm 0.023$ & $22.0 \pm 0.032$ \\
\hline
\end{tabular}

Values are the mean of three replicates \pm SD.

Biochemical estimations also indicated higher amount of total chlorophyll, carotenoid, protein, phenol and amino acid. In contrast, the higher concentration $(40 \%$ and $50 \%)$ treatments showed decreased amount than the above biochemical tests analysed in the $30 \%$ basal spray. Fay [8] have reported that Anabena azolla as a biofertilizer exhibited lignolysis and released phenolic compounds which induced profuse sporulation of the organism.

Nishida and Murata [9] reported the positive effect of nutrient content and soil structure on the addition of cyanobacteria. Ravishankar and Malliga [10] reported that Phormidium valderianum BDU 20041 showed a remarkable increase in percentage of germination. In addition they also proved that the Plectonema terebrans BDU 92192 has a significant effect on the growth of seedlings. The survival strategies of cyanobacteria occurring as crust in the rice fields under drought conditions were investigated by [11].

They observed fenugreek plant height, number of branches per plant; dry matter production and chlorophyll content were significantly high.

Immobilized as well as free living cyanobacterial applications were found to be distinctly advantageous over control as it enhanced significantly the various parameters of growth of rice plants such as shoot length and root length, fresh and dry weight of the plants chlorophyll and protein content over a period of 30 days [11]. [12] examined that seaweed liquid fertilizer increased the number of flowers in black gram. [13] explained cyanobacteria as a source of biofertilizer was 
the only sustainable and alternative source for the rice production.

Growth promoting substance from cyanobacteria influenced the amino acid and sugars in paddy field [14]. Many biologically active compounds are produced by microalgae [15]. Application of heterocystous and nonheterocystous cyanobacterial biofertilizers to the rice field clearly increased the number and weight of thegrains and also enhanced the NPK content of the soil [16]. There is a report on increase in germination percentage, shoot, root length and biochemical contents like proteins, carbohydrate, amino acids in the seedlings Hibiscus annus L. grown in effluent amended with cyanobacteria than in the effluent without cyanobacteria [17].

The cyanobacterial biomass when incorporated in the soil conserved organic matter, phosphorus, moisture and improves the chemical and physical structure of the soil $[18,19,22]$. Amther [20] has calculated that only $61 \%-77 \%$ of carbon available from photosynthesis can be retained during lignin utilization. Zeenat and Sharma [21] observed the effect of application cyanobacteria in combination with the chemical fertilizer diammonium phosphate on the growth on yield of tomatoes. From this, it is concluded that $30 \%$ of basal and foliar spray shows better enhanced biochemical and morphological rate. It also gives maximum fruit yield when compared to other treatments (control, 10\%, 20\%, 40\% and 50\%). This can be recommended for the better result of Hibiscus esculentus

\section{REFERENCES}

[1] Adhikary, S.P., (2000): A preliminarysurvey of algae of estuaries and wasted areas in Orissa. SeaweedRes.Utiln., 221-5.

[2] Rippka,R.,Derulles,J. Waterburry, J.B., Herdman, M., Stainer, R.Y., (1979): Genetic assignments, strain histories and properties of pure cultures of cyanobacteria J. en. Microbiol, 111, 1-61.

[3] Arnon, D.I., (1949): Copper enzyme in isolated chloroplast. Polyphenol oxidase in Beta vulgaris. Plant Physiol, 24, 1-15.

[4] Goodwin, M., Gillis., K.N., Rebers, P.A.. Smith, F., (1956):Colorimetric method for determination of sugars and related substances. Anal. Chem, 28, 300-356.

[5] Lowry, O.H., Rosebrough, N.J., Farr, A.L., Randall, R.J., (1195): Protein measurement with the Folin phenol reagent. J. Biol. Chem, 193, 265-275.

[6] Swain, T., Hillis, W.O., (1959): The phenolic consistents of Prunus domestic The quantitative estimation of phenolic constitution. J. Sci. Food Agric, 10, 63-68.

[7] Troll, W., Cannon, RK.,(1953): Determination of free amino acids. J Biol Chem, 200: 803.

[8] Fay, P., (1983): The Blue-greens (Cyanophytacyanobacteria)Edward Arnold (Pubs.), Baltimore, MD. pp.88.

[9] Nishida, L., Murata, N., (1996): Chilling sensitivity in plants and Cyanobacteria; the crucial contribution of membrane lipids. Annu. Rev. Plant Physiol.Plant Mol. Biol, 47, 541-68.

[10] Ravishankar, R., Malliga, P., (2003): Effect of Cyanobacterial extract on germination and seedling growth of black gram (Vigna mungo 7-9 variety) J. Swamy Bot, 20, 49-54.

[11] Deepak, R.D.D., Mishra, T.R., Mahapatro, S.K., Pateo and B.K., Sahu, (2000): Cadmium speciation in surface water of Rushikulya estuary, east coast of India. Ecol. Envi. \& Cons. 6, 217-221.

[12] Kumar, V., Mohan, V.R., (1997): The effect of seaweed liquid fertilizer on blackgram. Phycos, 36, 43-47.

[13] Prasad, B.N., (1996): Status of BG algal research in Nepal. In: Cyanobacterial biotechnology. Proceeding of the international symposium. Sep 18-21. pp38.

[14] Misra, B., kausik, B.D., (1989): Growth promoting substances of Cyanobacteria II. Detection of amino acids, sugar andauxin, proc. Indian Natn. Sci, Acad. BSS Nos, 56, 499-504.

[15] Melting, B., Pyne, J.W. (1996):Biologically active compounds from microalgae. Enzyme. Microb. Technol, 8, 386-394.

[16] Selvarani, V., (1983): Studies on the influence on nitrogen fixing and non-nitrogen fixing blue green algae on the soil, growth and field of paddy (Oryza sativa-TR50). M.Sc., thesis, Madurai kamaraj University, madurai, Tamilnadu, India. 
[17] Rajula, R.G., Padmadevi, S.N., (2000): Effect of industrial effluents without and with BGA on the growth and biochemical contents of the seedlings of Helianthus annus, L. Asian Jr. of Microbial Biotech. \& Env. Sc, 2, 151-154.

[18] Kaushik, B.D., (1993): Cyanobacterial research -An IARI pursuit. Proceedings of the National seminar on Cyanobacterial Research - Indian Scen, jan. 1921 1993. Edited by G. Subramanian, Bard Uni, Try. pp 32-49.

[19] Kaushik, Ummat, J. (1992): Reclamation of salt affected soils with blue green algae (Cyanobacteria):A Technology development. Proc. Natl. Seminar Biofertilizer Technology Transfer. Edited by Gangawne, L.V. Marathwa University, Aurangabad (India), 157.

[20] Amther, J.S., (2000): The McCree-devit-penning de vries Therney respiration paradigms 30 years later. Ann. of Botany, 86, 1-20.
[21] Zenat Rizvi, Sharma, V.K., (1990): Synergistic effect of EB and Dap on Tomato yield science ane Culture, $56,129-130$.

[22]. Abraham Christopher, P., Viswajith, V., Prabha, S., Sundhar, K., Malliga, P., (2007): Effect of coir pith based cyanobacterial basal and foliar biofertilizer on Basella rubra L. Acta agriculturae Slovenica, 89, 59 -63 .

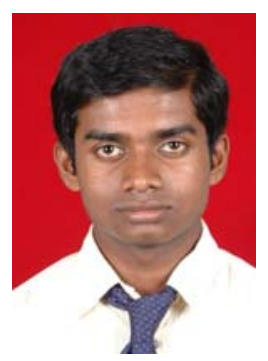

Mr. Abraham Christopher $P$ has 5 years of research experience in the field of Microbiology and has published more than 7 research papers in International and National conference. $\mathrm{He}$ is currently working as a Research Scholar, Department of Microbiology, Dr. M.G.R. University, Chennai-600 095, Tamil Nadu, India 